\title{
Why economists disregard economic methodology
}

\section{Working Paper}

Author(s):

Frey, Bruno S.

Publication date:

2000

Permanent link:

https://doi.org/10.3929/ethz-a-004373626

Rights / license:

In Copyright - Non-Commercial Use Permitted

Originally published in:

Working paper / Institute for Empirical Research in Economics 58 


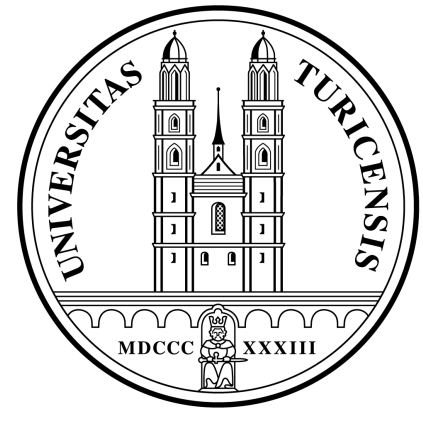

Institute for Empirical Research in Economics

University of Zurich

Working Paper Series

ISSN 1424-0459

Working Paper No. 58

Why Economists Disregard Economic Methodology

Bruno S. Frey

September 2000 


\title{
WHY ECONOMISTS DISREGARD ECONOMIC METHODOLOGY
}

\author{
Bruno S. Frey \\ (University of Zurich)
}

23 August 2000

\begin{abstract}
This paper advances two propositions, one concerning content, the other concerning research strategy.

(1) The advent of wide-spread internet publishing reduces the stifling impact of the refereeing process on the papers accepted and submitted to journals. Economics scholars are less bound to devoting a large part of their time and effort on formalisms. They have more leeway to concentrate on matters of content. This greater freedom also improves the chances of the advice and suggestions proposed by economic methodologists being put into practice.

(2) Economic methodology is only able to influence the practice of economics if it takes into account the incentives to which scholars are subjected when they want to pursue an academic career and become prominent. Incentives are transmitted by institutions; it is therefore necessary for economic methodology to analyse how institutions work and how they may change in the future. An attempt has been made here to look at the publication process in economics, and the impact the internet might have on the incentives to write and to do research.
\end{abstract}

Keywords: Economic methodology, economists, publishing, internet, institutions.

\section{ECONOMIC METHODOLOGY AND ECONOMIC PRACTICE}

Economic methodology has been strongly influenced by philosophy. Indeed, it can be considered to be a part of philosophy, as the normally used name 'philosophy of science' aptly conveys. The scholars engaged in this endeavour often have been educated in 
philosophy or at least have strong philosophical inclinations. They approach the subject in two steps: first they inquire what is the 'right' way of doing economics according to what they consider to be the 'scientific' standard, and then they exhort the economic researchers to act accordingly. Those who do not follow the principles laid down are considered not to be real scholars or to at least have a character deficiency.

The result of this approach is an almost total split between what economic methodologists prescribe and what economists do in their practical research. The gap is so vast that economists do not even take the trouble to reject the exhortations offered by the philosophers of science. They simply disregard them ${ }^{1}$.

The picture of preaching philosophers of science, and economists totally disregarding them, is perhaps less surprising where fundamental issues are concerned. It would be too naive to expect practical economists to change completely because some 'outsiders' advise them to do so. An example would be the sort of issues addressed by practical economists, which tend to be self-defined within economic science rather than being reactions to what may be seen to occur in the 'real' world (see Frey and Eichenberger 1992). But the advice offered by economic methodology is also disregarded when it comes to specific research procedures. A pertinent example is the problems arising when the 'best' econometric result is presented after having run virtually thousands of estimates. The statistical tests, in particular the t-values, are nevertheless presented as if the data had been used only once. This is mistaken (see the special issue of the Journal of Economic Methodology 7, June 2000). Another example is the interpretation of 'statistical significance' in empirical economic research in terms of substantive importance (see McCloskey 1997). A high tvalue associated with an estimated parameter is taken to mean that the respective relationship reflects an important empirical connection in the real world. Though modern economists are generally well-trained in statistics, and therefore actually know that such an 
inference is mistaken, it is routinely undertaken. It has been shown (McCloskey and Ziliak 1996) that a vast majority of articles recently published in the leading economics journal, the American Economic Review, interpret statistical significance as substantive significance. As pointed out, economists indeed know better. How is it possible then that they do not heed the methodological advice?

\section{INCENTIVES FOR ECONOMISTS}

Scholars in academia are strongly motivated by extrinsic incentives. Most of them seek to pursue a career leading them to the top - a full professorship at a good university - and a corresponding income. In addition they wish to enjoy a good reputation and fame with their colleagues. This is not to say that intrinsic incentives, i.e. an interest in research for its own sake, is unimportant. But especially young scholars who have to establish themselves in the profession are forced to first meet the externally imposed requirements with regard to their career. In today's world, there are only a few people who can, and are willing to spend their lives as 'Privatgelehrter'. In most countries, and especially in the United States, academic success today depends on the number of publications obtained in professional journals, as well as on the number of citations potentially generated by them and collected in the Social Science Citation Index. A generally recognized ranking of journals exists in economics. Only refereed reviews are considered acceptable; books are of lesser importance, mainly because they are often less strictly refereed.

Over the last decades, the refereeing process has become increasingly demanding (see Ellison 2000a). There is no way out: those who want to succeed have to bow to the wishes of the journal referees.

A paper may be seen to be composed of two aspects: 
(a) The content of the article, in particular the basic idea and the contribution to the academic discussion;

(b) The formalisms, in particular the mathematical model by which the idea is expressed, the econometric technique with which the propositions are tested, and the presentation which has to follow established rules. Economists have to write in a terse style, are not allowed any deviations from the main argument, and verbal ramifications or emotional arguments are not tolerated.

Referees of economic journals devote most of their attention, if not all their attention, to formalism and technicalities. The content of the article, and the insights it provides for understanding the real world, are of secondary importance. Many referees shun evaluating the content because this necessarily involves value judgements, which in modern economics are considered to be 'unscientific' because they are subjective. In contrast, the formal aspects of a paper can be evaluated in a (seemingly) objective way according to the rules of the trade. This is particularly important in a global market for academic economists (see Frey and Eichenberger 1997), where it is increasingly difficult to know anything about the material content of an article. Referees therefore resort to evaluating the formalisms (Is the mathematical model correct? Have the most advanced techniques been used for the econometric estimates?). As a result, the length of time between first submission and final acceptance has dramatically lengthened. Thirty years ago it was at most six to nine months, and today it is two or even three years.

The referees' emphasis on formalism, and the relative disregard for relevance and originality, not only affects the submitters of papers but also has an external effect on all scholars pursuing an academic career. They all have to respond to the referees' change of emphasis and are forced to spend increasing amounts of time and effort on purely formal aspects of academic work. In particular, most, if not all, of the time spent on revising the 
paper is directed towards improving the mathematical model or the econometric estimates - often with little or no improvement in actual content. An author has to meet the demands of two, and sometimes three, referees. But it is quite unlikely that a group of referees agrees that a specific innovative idea contained in a paper is correct and worth being undertaken, not least of all because such new ideas threaten the importance of the previous work by the experts acting as referees. Original ideas are therefore difficult to get through the existing refereeing process. This leads to a self-selection in terms of economics scholars engaging in an academic career and in terms of papers being submitted. There is considerable bias in the direction of formalistic papers making minor addition to accepted knowledge (see e.g. Mayer 1993, Blaug 1997, Reder 1999).

\section{THE ROLE OF INSTITUTIONS}

I have argued that the advice offered by economic methodologists has no effect on practical economic research, because academic economists are forced to follow the dictates imposed by the referees in the publication process. Incentives matter, an aspect serenely disregarded in the philosophy of science. As long as the external incentives for scholars are as at presently, the preaching of economic philosophers is to no avail. The large gap between economic methodology and economic practice will remain.

The relevant question is therefore: Are the demands placed on the authors of papers by the referees as given or can they be changed? Or in other words: Are the institutions governing the career of academic economists immutable and, if not, how might they change? A look at other disciplines suggests that many different institutional ways of organizing science are feasible. Especially in the natural sciences, the referees impose much less severe requirements for change, and accordingly the time between initial submission and final acceptance of a paper is considerably shorter (Ellison 2000b). But institutional variation 
exists also in the social sciences. In the United States, for example, the law journals are run by (graduate) students - an arrangement almost inconceivable for economists steeped in the traditions of their discipline. The authors therefore have an incentive to write easily readable papers, and to carefully put them into the context of existing knowledge in order to have a chance of being accepted for publication. It is however most unlikely that economics journals by themselves change their requirements. The presently existing institutional arrangements have evolved over decades, and there are many forces maintaining the existing equilibrium. In particular, those economic academics, who were successful in the system in the past, have a vested interest in resisting any change. They are interested in decrying lower demands by referees as a lowering in academic standards. An institutional change in the publishing, and hence career requirements of economists, must be induced from outside. The strongest influence will come from technological innovations.

\section{THE FUTURE OF ECONOMICS PUBLISHING}

In the last two or three years, electronic publishing has had a considerable impact on academic economics, but it may be speculated that its full impact is yet to come. Most reputable economics departments and research institutes have placed their working paper series on the internet, and are therefore publicly available instantaneously and at essentially zero cost. Working papers differ in an essential way from journal publications: working papers are not refereed and can be put on the web. The technological change in the form of internet publishing has opened up a new way of publishing one's findings without having to pass the entry barrier of the refereeing process. The monopoly position of the journals is at least partly undermined because citations of working papers are included in the Social Science Citation Index. Moreover, any economics scholar, who wants to keep abreast of 
the newest developments in his or her profession, must take the electronically published working papers into account. The importance of working papers is therefore likely to rise relative to journal publications. In the future, working papers will probably be counted as part of the legitimate output of a scholar, and will be relevant for career decisions.

If this institutional development indeed takes place, the way professional papers in economics are written will also change. Content, in terms of contributing new insights, as well as originality, will become more important than under the present refereeing system. Internet publishing opens up the scope of publications and allows more innovative and unorthodox contributions to be published and made known to the scientific community. The other scholars, as prospective readers, will become aware of and exposed to these ideas rather than being restricted to the articles published in refereed journals. In contrast, formalism for formalism's sake, favoured by the present refereeing system, will decrease in importance. At the same time, academic economics papers are opened to a broader public, including politicians and public officials, via internet publishing. This provides a stronger incentive to academics to write papers which are of interest to practicians, and these are certainly those which focus on content rather than on technicalities.

But how will the prospective readers be able to choose between all these working papers? Already today the output is huge, and it is virtually impossible to digest the amount of literature, even in a narrow sub-field of economics. One rather imperfect signal may be the quality of the department or institute editing the working paper series. It is to be expected that some such series impose an equally stringent refereeing process as applies to journals. The next logical step is to formally establish e-journals, of which several already exist in economics, and to guarantee the reader that papers will be put out only if they meet the established journal standards. This is certainly possible, but it robs the internet of one of its essential characteristics, namely speed. The three to four rounds of revisions required from 
the authors would lead to the essentially same slow publication (two or even three years after first submission) typical of today's journals. Moreover, each scholar is free to publish an early version of a paper on his or her home page, so that the problem of having a no longer digestible flow of contributions remains unsolved.

The interactive nature of the internet, however, offers new possibilities. Journals by their very nature apply negative criteria. Of all the papers submitted to them, they reject those papers whose quality they find to be lacking. The internet permits a positive approach. Quite some time ago, Gordon Tullock suggested (in personal communication with the author) that in front of each paper put on the internet a space should be left in which readers could write their evaluation and critique of a paper. If a paper has been positively evaluated by, say, several Nobel Prize winners, other scholars have an added incentive to read the paper. This solution also has its problems. It assumes that 'netiquette' is observed, because otherwise such endorsements by famous economists can be faked. The solution also works if anybody faking an entry can be made liable.

The Social Science Research Network (www.ssrn.com) has chosen another way of ranking their on-line papers. Full document downloads are counted for each paper and the result is shown with the title of the paper. Thus, each on-line search provides such a quantitative ranking. In addition, the papers are assigned to network journals covering a wide range of economic topics. Each journal offers its own ranking of top ten articles, and there is also a list of overall 'bests'.

Another solution is to have various levels of quality within each series, for instance standard, bronze, silver and gold. This is the procedure envisaged by the 'Quality-Rated Journals of Economic Theory and Macroeconomics', as described in The Economist, 5 August 2000: 71). Most articles will be accepted in the standard class, but if the author is prepared to revise according to the suggestions of the referees, he or she may move 
upwards. As revisions still take as long as journals on paper, the 'gold papers' considered to be of highest quality by the editors and referees will also be the most dated.

\section{CONSEQUENCES FOR ECONOMIC METHODOLOGY}

This paper advances two propositions, one concerning content, the other concerning research strategy.

(1) The advent of wide spread internet publishing reduces the stifling impact of the refereeing process on the papers accepted and submitted to journals. Economics scholars are less bound to devote a large part of their time and effort on formalisms. They have more leeway to concentrate on matters of content. This greater freedom also improves the chances that the advice and suggestions proposed by economic methodologists are put into practice, provided they are of practical use for research. The dominance of orthodoxy is reduced. But at the same time the competition between papers is intensified, so that only methodological concerns held to be useful by practical economists have an impact on the profession.

(2) Economic methodology is only able to influence the practice of economics if it takes into account the incentives to which scholars are subjected when they want to pursue an academic career and become prominent. Incentives are transmitted by institutions; it is therefore necessary for economic methodology to analyse how institutions work and how they may change in the future. An attempt has been made here to look at the publication process in economics, and the impact the internet might have on the incentives to write and to do research. 


\section{ACKNOWLEDGEMENTS}

I am grateful to Matthias Benz, Reiner Eichenberger, Reto Jegen, Stephan Meier and Alois Stutzer for helpful comments on an earlier version.

\section{NOTE}

(1) As always, there are exceptions. When economists are getting on in age, they sometimes feel an urge to engage in methodological considerations, but they are often ill equipped to do so (see e.g. Hahn 1992 and the criticism by Hargreaves Heap 2000).

\section{REFERENCES}

Blaug, M. (1997) 'Ugly Currents in Economics. Facts or Fiction?’, Conference on Realism in Economics, Rotterdam, 14-15 November.

Ellison, G. (2000a) 'Evolving Standards for Academic Publishing: A q-r Theory', NBER Working Paper No. W7805, July.

Ellison, G. (2000b) 'The Slowdown of the Economics Publishing Process', NBER Working Paper No. W7804, July.

Frey, B.S. and Eichenberger, R. (1992) 'Economics and Economists: A European Perspective', American Economic Review 82: 216 - 220.

Frey, B.S. and Eichenberger, R. (1997) 'Economists: First Semester, High Flyers, and UFOs', in P.A.G van Bergeijk, A. Bovernberg, E.E.C. van Damme and J. van Sinderen (eds) Economic Science and Practice: The Roles of Academic Economists and Policy-makers, Cheltenham UK and Brookfield USA: Edward Elgar: 15 - 48.

Hahn, F. (1992) 'Reflections', Royal Economic Society Newsletter, April: 5. 
Hargreaves Heap, S. (2000) 'Methodology now', Journal of Economic Methodology 7: 95 -108 .

Mayer, T. (1993) Truth versus Precision in Economics, Aldershot: Edward Elgar.

McCloskey, D. (1997) The Vices of Economists; The Virtues of the Bourgeoisie, Amsterdam: University of Amsterdam Press and Ann Arbor: University of Michigan Press.

McCloskey, D. and Ziliak, S. (1996) 'The Standard Error of Regression', Journal of Economic Literature 34: 97-114.

Reder, M.W. (1999) Economics. The Culture of a Controversial Science, Chicago and London: University of Chicago Press. 


\section{Working Papers of the Institute for Empirical Research in Economics}

No.

1. Rudolf Winter-Ebmer and Josef Zweimüller: Firm Size Wage Differentials in Switzerland: Evidence from Job Changers, February 1999

2. Bruno S. Frey and Marcel Kucher: History as Reflected in Capital Markets: The Case of World War II, February 1999

3. Josef Falkinger, Ernst Fehr, Simon Gächter and Rudolf Winter-Ebmer: A Simple Mechanism for the Efficient Provision of Public Goods - Experimental Evidence, February 1999

4. Ernst Fehr and Klaus M. Schmidt: A Theory of Fairness, Competition and Cooperation, April 1999

5. Markus Knell: Social Comparisons, Inequality, and Growth, April 1999

6. Armin Falk and Urs Fischbacher: A Theory of Reciprocity, April 1999

7. Bruno S. Frey and Lorenz Goette: Does Pay Motivate Volunteers?, May 1999

8. Rudolf Winter-Ebmer and Josef Zweimüller: Intra-firm Wage Dispersion and Firm Performance, May 1999

9. Josef Zweimüller: Schumpeterian Entrepreneurs Meet Engel's Law: The Impact of Inequality on InnovationDriven Growth, May 1999

10. Ernst Fehr and Simon Gächter: Cooperation and Punishment in Public Goods Experiments, June 1999

11. Rudolf Winter-Ebmer and Josef Zweimüller: Do Immigrants Displace Young Native Workers: The Austrian Experience, June 1999

12. Ernst Fehr and Jean-Robert Tyran: Does Money Illusion Matter?, June 1999

13. Stefan Felder and Reto Schleiniger: Environmental Tax Reform: Efficiency and Political Feasibility, July 1999

14. Bruno S. Frey: Art Fakes - What Fakes?, An Economic View, July 1999

15. Bruno S. Frey and Alois Stutzer: Happiness, Economy and Institutions, July 1999

16. Urs Fischbacher, Simon Gächter and Ernst Fehr: Are People Conditionally Cooperative? Evidence from a Public Goods Experiment, July 2000

17. Armin Falk, Ernst Fehr and Urs Fischbacher: On the Nature of Fair Behavior, August 1999

18. Vital Anderhub, Simon Gächter and Manfred Königstein: Efficient Contracting and Fair Play in a Simple Principal-Agent Experiment, August 1999

19. Simon Gächter and Armin Falk: Reputation or Reciprocity?, September 1999

20. Ernst Fehr and Klaus M. Schmidt: Fairness, Incentives, and Contractual Choices, September 1999

21. Urs Fischbacher: $z$-Tree - Experimenter's Manual, September 1999

22. Bruno S. Frey and Alois Stutzer: Maximising Happiness?, October 1999

23. Alois Stutzer: Demokratieindizes für die Kantone der Schweiz, October 1999

24. Bruno S. Frey: Was bewirkt die Volkswirtschaftslehre?, October 1999

25. Bruno S. Frey, Marcel Kucher and Alois Stutzer: Outcome, Process \& Power in Direct Democracy, November 1999

26. Bruno S. Frey and Reto Jegen: Motivation Crowding Theory: A Survey of Empirical Evidence, November 1999

27. Margit Osterloh and Bruno S. Frey: Motivation, Knowledge Transfer, and Organizational Forms, November 1999

28. Bruno S. Frey and Marcel Kucher: Managerial Power and Compensation, December 1999

29. Reto Schleiniger: Ecological Tax Reform with Exemptions for the Export Sector in a two Sector two Factor Model, December 1999

30. Jens-Ulrich Peter and Klaus Reiner Schenk-Hoppé: Business Cycle Phenomena in Overlapping Generations Economies with Stochastic Production, December 1999

31. Josef Zweimüller: Inequality, Redistribution, and Economic Growth, January 2000

32. Marc Oliver Bettzüge and Thorsten Hens: Financial Innovation, Communication and the Theory of the Firm, January 2000

33. Klaus Reiner Schenk-Hoppé: Is there a Golden Rule for the Stochastic Solow Growth Model? January 2000

34. Ernst Fehr and Simon Gächter: Do Incentive Contracts Crowd out Voluntary Cooperation? February 2000

35. Marc Oliver Bettzüge and Thorsten Hens: An Evolutionary Approach to Financial Innovation, July 2000

36. Bruno S. Frey: Does Economics Have an Effect? Towards an Economics of Economics, February 2000

37. Josef Zweimüller and Rudolf Winter-Ebmer: Firm-Specific Training: Consequences for Job-Mobility, March 2000

The Working Papers of the Institute for Empirical Research in Economics can be downloaded in PDF-format from http://www.unizh.ch/iew/wp/ 


\section{Working Papers of the Institute for Empirical Research in Economics}

No.

38. Martin Brown, Armin Falk and Ernst Fehr: Contract Inforcement and the Evolution of Longrun Relations, March 2000

39. Thorsten Hens, Jörg Laitenberger and Andreas Löffler: On Uniqueness of Equilibria in the CAPM, July 2000

40. Ernst Fehr and Simon Gächter: Fairness and Retaliation: The Economics of Reciprocity, March 2000

41. Rafael Lalive, Jan C. van Ours and Josef Zweimüller: The Impact of Active Labor Market Programs and Benefit Entitlement Rules on the Duration of Unemployment, March 2000

42. Reto Schleiniger: Consumption Taxes and International Competitiveness in a Keynesian World, April 2000

43. Ernst Fehr and Peter K. Zych: Intertemporal Choice under Habit Formation, May 2000

44. Ernst Fehr and Lorenz Goette: Robustness and Real Consequences of Nominal Wage Rigidity, May 2000

45. Ernst Fehr and Jean-Robert Tyran: Does Money Illusion Matter? REVISED VERSION, May 2000

46. Klaus Reiner Schenk-Hoppé: Sample-Path Stability of Non-Stationary Dynamic Economic Systems, Juni 2000

47. Bruno S. Frey: A Utopia? Government without Territorial Monopoly, June 2000

48. Bruno S. Frey: The Rise and Fall of Festivals, June 2000

49. Bruno S. Frey and Reto Jegen: Motivation Crowding Theory: A Survey of Empirical Evidence, REVISED VERSION, June 2000

50. Albrecht Ritschl and Ulrich Woitek: Did Monetary Forces Cause the Great Depression? A Bayesian VAR Analysis for the U.S. Economy, July 2000

51. Alois Stutzer and Rafael Lalive: The Role of Social Work Norms in Job Searching and Subjective Well-Being, July 2000

52. Iris Bohnet, Bruno S. Frey and Steffen Huck: More Order with Less Law: On Contract Enforcement, Trust, and Crowding, July 2000

53. Armin Falk and Markus Knell: Choosing the Joneses: On the Endogeneity of Reference Groups, July 2000

54. Klaus Reiner Schenk-Hoppé: Economic Growth and Business Cycles: A Critical Comment on Detrending Time Series, August 2000

55. Armin Falk, Ernst Fehr and Urs Fischbacher: Appropriating the Commons - A Theoretical Explanation, September 2000

56. Bruno S. Frey and Reiner Eichenberger: A Proposal for a Flexible Europe, August 2000

57. Reiner Eichenberger and Bruno S. Frey: Europe's Eminent Economists: A Quantitative Analysis, September 2000

58. Bruno S. Frey: Why Economists Disregard Economic Methodology, September 2000

The Working Papers of the Institute for Empirical Research in Economics can be downloaded in PDF-format from http://www.unizh.ch/iew/wp/

Institute for Empirical Research in Economics, Blümlisalpstr. 10, 8006 Zürich, Switzerland

Phone: 004116343705 Fax: 004116344907 E-mail: bibiewzh@iew.unizh.ch 